\title{
TAXONOMICAL STUDIES ON ACTIVE Streptomyces ISOLATES FROM EGYPTIAN SOIL
}

(Received: 22.4.2009)

\author{
By \\ F. M. Rashad, N. H. Abd El -Nasser*, E. I. Dawoud and F. H. M. Motawe * \\ Department of Agricultural Microbiology, Faculty of Agriculture, Cairo University, Giza, Egypt. \\ * Department of Microbial Chemistry, National Research Centre, Dokki, Giza, Egypt.
}

\begin{abstract}
Two hundred putative streptomycete isolates were recovered from agricultural soil samples collected from Assiut (Kossia), Dakahlia (Belqas), and Giza Governorates of Egypt. Only 25 of these isolates showed incongruous antimicrobial activities against reference Gram-positive, Gram-negative species of bacteria, yeast and filamentous fungi. These active isolates were characterized morphologically, culturally, physiologically, biochemically and chemotaxonomically to species level. The comparative analysis of the different characteristics using SPSS statistical software divided the 25 bioactive streptomycetes into 6 clusters. The dominant clusters were Streptomyces lydicus followed by S. atroolivaceus.
\end{abstract}

Key words: antimicrobial activity - cell wall analysis - numerical taxonomy.- Streptomyces sp.

\section{INTRODUCTION}

Actinomycetes comprise an extensive and diverse group of mycelial bacteria and have substantial practical significance. They are primarily soil inhabitants and considered as one of the major communities of soil microbial population, and their occurrence is greatly influenced by the environmental conditions (Basilio et al., 2003). Streptomyces is the most commonly isolated genus of actinomycetes. It is very important, both ecologically and medically as one of the major prolific producers of economically important bioactive secondary metabolites such as antibiotics, vitamins, herbicides, pesticides, anti-parasitic, and enzyme like cellulase and xylanase used in waste treatment (McCarthy and Williams, 1992; Sanglier et al., 1996; Horan, 1999; Lazzarini et al., 2000 and Takahashi and Omura, 2003). They can be distinguished from all other actinomycetes in morphological, cultural, physiological and chemotaxonomical characteristics (Shirling and Gottlieb, 1966; Soput et al., 1967; Lechevalier, and Uechevalier, 1970 \& 1980; Minnikin et al., 1980; Alderson et al., 1985 and Christova et al., 1995).

A considerable step in advance of the taxonomy of the streptomycetes is the numerical classification of Williams et al. (1983). This study was formed on the basis of the classification of the species of genus Streptomyces in Bergey's manual (Williams et al., 1989). Isolation and screening of
Streptomyces for the production of novel bioactive products has been intensively pursued along by scientists.

In the present research, isolation and biological activities as well as characterization of active streptomycetes isolates have been studied.

\section{MATERIALS AND METHODS}

\subsection{Sampling}

Ten cultivated soil samples were collected in sterile plastic bags at a depth of $15-20 \mathrm{~cm}$, from Assiut (Kossia), Dakahlia (Belqas) and Giza Governorates and air dried at room temperature.

\subsubsection{Isolation of streptomycetes colonies}

Ten grams of soil sample were homogenized in $90 \mathrm{ml}$ buffered phosphate solution ( $\mathrm{pH}$ 7.0). Soil suspension was serially diluted and plated onto starch nitrate agar plates (Waksman,1962) following pour plating technique; the plates were incubated at $28{ }^{\circ} \mathrm{C}$ for 7-14 days. Firm cartilaginous rough chalky colonies of streptomycetes were selected and purified.

\subsubsection{Determination of antimicrobial activity}

The purified isolates of streptomycetes were cultivated for 5 days on starch nitrate agar plates at $28{ }^{\circ} \mathrm{C}$. A disk of $0.8 \mathrm{~mm}$ diameter of the resulted culture was cut by sterile cork borer and aseptically transferred to inoculate $250 \mathrm{ml}$ Erlenmeyer flasks containing $50 \mathrm{ml}$ of sterile starch nitrate broth medium and allowed to grow at $28-30{ }^{\circ} \mathrm{C}$ for 5 days at $180 \mathrm{rpm}$ on a rotary shaker ( New Brunswick Scientific, Edison, N. J., 
USA). The broth culture was aseptically filtrated through Whatman filter paper No. 1 (Shirling and Gottlieb, 1968). A sterile cork borer was used to make holes $(0.8 \mathrm{~mm}$ in diameter) in the plates seeded with the test organism, then only $0.1 \mathrm{ml}$ of each filtrate was aseptically transferred into each hole and incubated at $28{ }^{\circ} \mathrm{C}$ for 1 and 3 days for bacteria and fungi, respectively. Antagonism was determined by measuring the size of inhibition zone around holes in millimeter.

\subsubsection{Organism test}

Antibacterial activities of streptomecete isolates were tested in vitro against the following microorganisms : Gram negative bacteria (Escherichia coli NRRL B-3704), Gram positive bacteria (Bacillus cereus*, B.subtilis NRRL B941, Staphylococcus aureus*, Streptococcus pyogenes*), yeasts (Candida albicans* and Saccharomyces cerivesiae*) and fungi (Asperagillus niger NRRLA-326, A. flavus NRRL A-1957, Macrophomina phaseoli NRRL A-62743, Botrytis allii NRRL A-2502, Deplodiaoryzae ATCC-10936, Fusarium oxysporium NRRL A- 2018, Trichoderma viride NRRL A63065).

* These microorganisms were kindly provided by the Department of Microbiology, Ain Shams University.

\subsubsection{Characterization of the active isolates}

Pure colonies of active streptomycetes were individuated by morphological, cultural, physiological and chemotaxonomical characters in accordance with the guidelines established by the International Streptomyces Project (Shirling and Gottlieb, 1966) and Bergey's Manual of Systematic Bacteriology (Locci, 1989). The characteristics of pure isolates in various media were recorded after incubation for 7 to 14 days at $28{ }^{\circ} \mathrm{C}$ (Oskay et al., 2004). The morphological observations (Spore chain morphology and spore surface ornamentation) were made with a light and transmission electron- microscopy (Zeiss EM-10 West Germany) using the methodology of Tresner et al. (1961). A range of phenotypic properties was examined using the standard procedures of Williams et al. (1983). Cultural characters including color of the spore mass, pigmentation of substrate mycelium and diffusible pigments were visually estimated by using Methuen Hand Book Color of Kenneth (1958). Physiological and chemotaxonomical features include utilization of different carbon sources, activities of lipolytic, proteolytic and lecithinase enzymes; pectin, chitin, xanthine and arbutin decomposition; melanin synthesis, nitrate reduction, hydrogen sulphide production, cell wall analysis and whole-cell sugars (Shirling and Gottlieb 1966; Szabo, et al., 1978).

\subsubsection{Statistical analysis}

The SPSS for windows release 6.0 statistical software group has been used to generate phenograms. Data were examined using the simple matching $\left(\mathrm{S}_{\mathrm{Sm}}\right.$; Sokal and Michener,1958) coefficient. Tree was generated by the UPGMA algorithm. The phenogram was printed and further evaluated using different systematic and determinative bacteriological manuals (Bergey's Manual of Systematic Bacteriology, Locci, 1989)

\section{RESULTS \\ 3.1. Screening of isolated streptomycetes for antimicrobial activities}

A total of 200 streptomycetes isolates was recovered from soil samples collected from different areas in Egypt. The antimicrobial activity of the isolates revealed that only $25(12.5 \%)$ have a relatively inconsistent potency against the test organisms as shown in Table (1). Of the 25 isolates, 2 were active against both $E$. coli and $B$. cereus, B. subtilis, Staphylococcus aureus and Streptococcus pyogenes; 6 against Gram positive bacteria. Among them 3 of the isolates were very weak and/or weak active ( $\varnothing 14-18 \mathrm{~mm}$ ) against E. coli, 9 with variable activity $(\varnothing 12-20 \mathrm{~mm})$ against $B$. cereus, 18 against $B$. subtilis ( $\varnothing$ 14- 26 $\mathrm{mm}), 21$ against Staphylococcus aureus (Ø 14 $30 \mathrm{~mm}$ ) and 18 against Streptococcus pyogenes (Ø $14-26 \mathrm{~mm}$ ). Concerning fungi, it is obvious that all these active strepyomycetes were futile to inhibit the growth of Saccharomyces cerevisiae as a target organism and only 13 isolates inhibited the growth of Candida albicans with variable rates as indicated by the measured inhibition zones $(\varnothing 14-30 \mathrm{~mm})$. Pertaining filamentous fungi, all the 25 isolates subdued the growth of Asperagillus niger in dissident levels (Ø $14-30$ $\mathrm{mm}), 5$ against Asperagillus flavus, 21 against. Macrophomina phaseoli, 22 against Botrytis allii, 2 against Deplodia-oryzae, 1 against Fusarium oxysporium and 9 against Trichoderma viride. It is conspicuous that the isolate \# 200 was equally superior in potency against Staphylococcus aureus, Candida albicans and Asperagillus niger as compared to the other active isolates.

\subsection{Morphological characteristics}

The light microscopic examination of the 25 active streptomycetes isolates indicated that 7 (28\%) possessed spore-bearing hyphae of type straight (Fig. 1-A), 1 (4\%) possessed hooks (Fig.1-B) and 15 (60\%) possessed an extended 


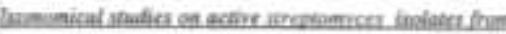

Ftle (1): Antimicrobial activity of active Sereptomycen isolates against bacteria, geast and fungi (Zooe of inhibition, mani.

\begin{tabular}{|c|c|c|c|c|c|c|c|c|c|c|c|c|c|}
\hline \multirow[b]{2}{*}{$\begin{array}{l}\text { Sirain } \\
\text { Sae. }\end{array}$} & \multicolumn{5}{|c|}{ Macteria } & \multirow{2}{*}{ 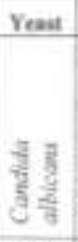 } & \multicolumn{7}{|c|}{ Fang } \\
\hline & 这 & $\frac{\frac{a}{4}}{\frac{1}{2}} \frac{2}{2}$ & $\frac{a}{\frac{3}{2}} \frac{2}{2}$ & $\frac{7}{\frac{7}{8}}$ & 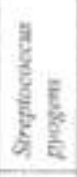 & & 롤 है & 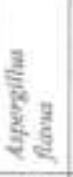 & 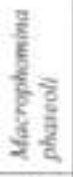 & 受 & 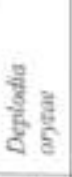 & $\frac{5}{\frac{5}{2}} \frac{5}{5}$ & $\frac{\frac{2}{2}}{\frac{2}{2}} \frac{y}{\frac{y}{2}}$ \\
\hline 1 & 0 & 30 & 20 & 16 & 16 & 20 & 14 & 0 & 14 & 20 & 0 & 0 & 14 \\
\hline 2 & 0 & 0 & 14 & 14 & 14 & 0 & 14 & 0 & 14 & 14 & 0 & 0 & 0 \\
\hline 3 & 0 & 0 & 0 & 0 & 6 & 0 & 20 & 0 & 0 & 0 & 0 & 0 & e \\
\hline 5 & 18 & 14 & 20 & 20 & 22 & I4. & 20 & 0 & 16 & 14 & 0 & 0 & 0 \\
\hline 8 & 0 & 20 & 26 & 24 & 22 & 14 & 14 & 0 & 14 & 20 & 9 & 0 & 14 \\
\hline II & $\theta$ & 15 & 14 & 16 & 22 & 14 & 14 & 0 & 14 & 20 & 0 & 0 & 14 \\
\hline 13 & 0 & 0 & 17 & 14 & 14 & 0 & 14 & 0 & 14 & 22 & 0 & 0 & 0 \\
\hline 15 & 0 & 0 & 0 & 0 & 0 & 0 & 20 & 16 & 14 & 0 & 0 & 0 & 0 \\
\hline 2 & 0 & 0 & 18 & 18 & 24 & 14 & 14 & 0 & 14 & 24 & 0 & 0 & 0 \\
\hline 24 & 0 & 16 & 16 & 16 & 22 & 14 & 14 & 0 & 14 & 16 & 0 & 0 & 16 \\
\hline $2 ?$ & 0 & 14 & 16 & 16 & 22 & 16 & 14 & 0 & 14 & 18 & 14 & 0 & 12 \\
\hline 29 & 18 & 0 & 16 & 14 & 26 & 0 & 16 & 0 & 14 & 14 & 0 & 0 & 0 \\
\hline 31 & 0 & 0 & 0 & 16 & 0 & 16 & 16 & 14 & 0 & 20 & $\theta$ & 0 & 0 \\
\hline 32 & 0 & 14 & 14 & 16 & 18 & 14 & 14 & 0 & 14 & 14 & 0 & 0 & 14 \\
\hline 34 & 0 & 0 & 16 & 14 & 14 & 0 & 14 & 0 & 14 & 14 & 0 & 0 & 0 \\
\hline 44 & 0 & 16 & 16 & 16 & 18 & 14 & 14 & 0 & 14 & 14 & 0 & 0 & 14 \\
\hline 63 & 16 & 12 & 24 & 24 & 20 & 0 & 24 & 0 & 14 & 18 & 0 & 0 & 0 \\
\hline 65 & 0 & 0 & 0 & 0 & 0 & 0 & 20 & 16 & 14 & 0 & 0 & 0 & 0 \\
\hline 81 & 0 & 0 & 16 & 14 & 16 & 14 & 14 & 0 & 14 & 14 & 0 & 0 & 14 \\
\hline 101 & 0 & 0 & 14 & 14 & 14 & 0 & 16 & 0 & 14 & 16 & 0 & 16 & 0 \\
\hline 164 & 0 & 0 & 15 & 14 & 14 & 0 & 16 & 0 & 14 & 16 & 0 & 0 & 0 \\
\hline 106 & 0 & 0 & 16 & 14 & 14 & 0 & 14 & 0 & 14 & 14 & 0 & 0 & $\theta$ \\
\hline 108 & 0 & 0 & $\theta$ & 0 & 0 & 0 & 16 & 0 & 18 & 20 & 16 & 9 & 14 \\
\hline 109 & 0 & 0 & 0 & 16 & 0 & 16 & 14 & 14 & 0 & 20 & 0 & 0 & 0 \\
\hline 200 & 0 & 0 & 0 & 30 & 0 & 30 & 30 & 14 & 0 & 20 & 0 & 0 & 0 \\
\hline
\end{tabular}



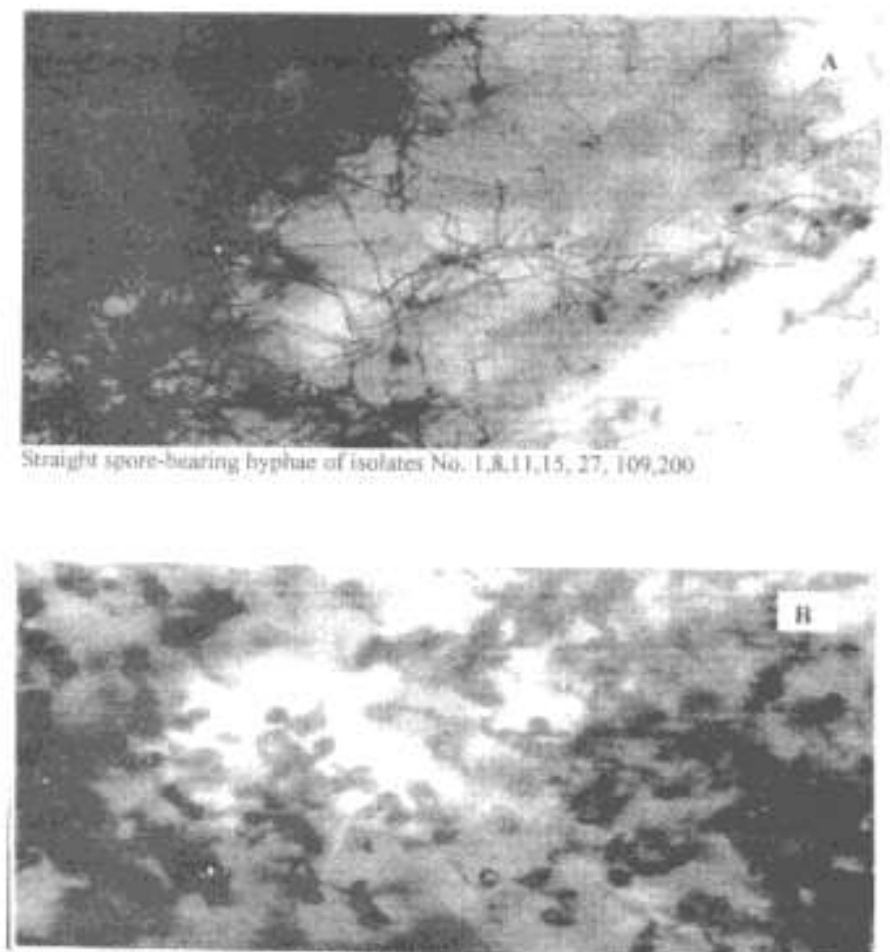

Henok spare-bearine hyphac of isolute No [?

Fig. (1) Morpholngical characteristies of hearing by phat of streptomycetes isodates (Ploutograph 400X) (Coatinued) 


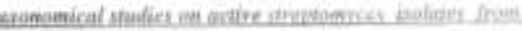
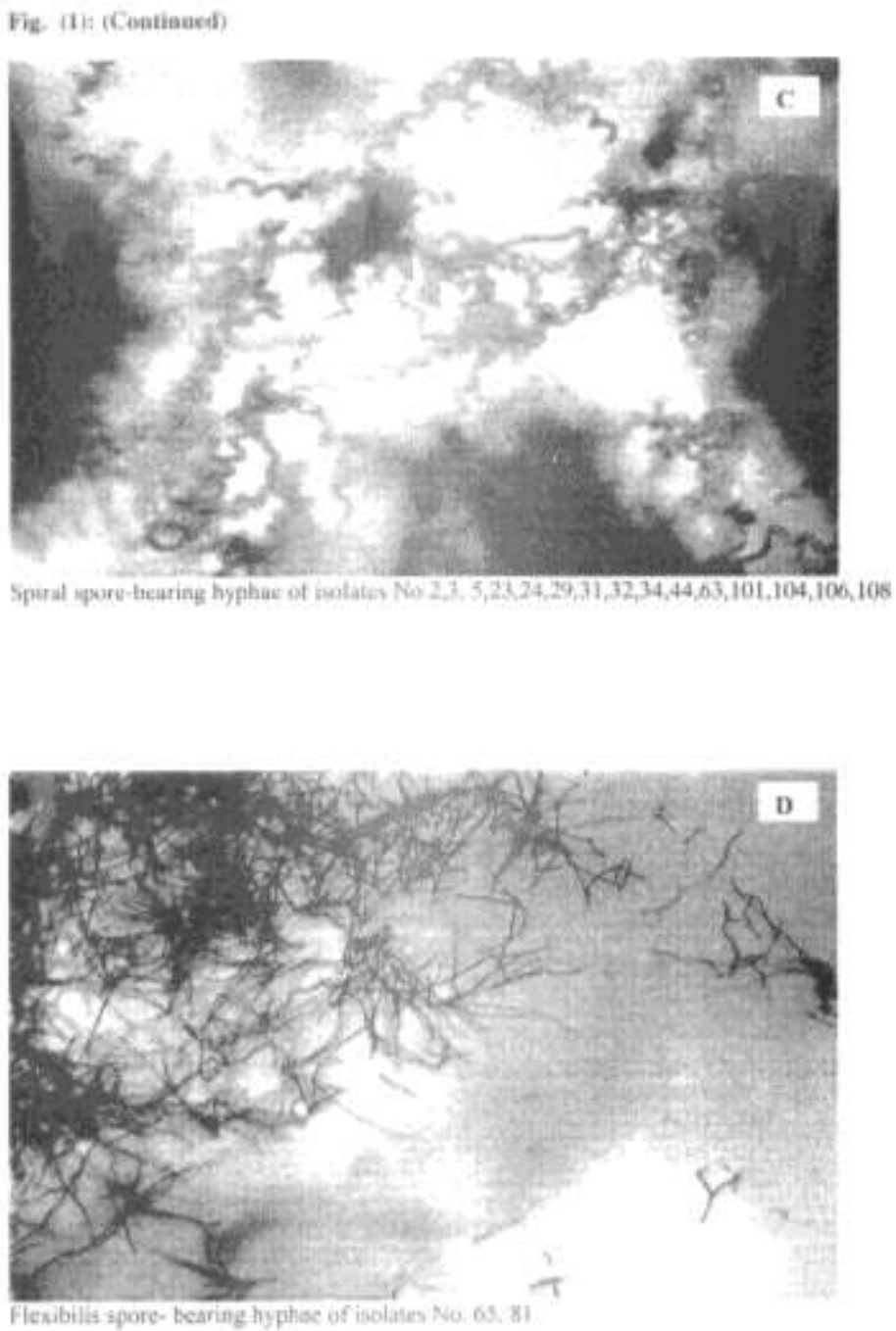

Fiesibilis spore- Bearing hyphoc of isolates No. 65, 81 


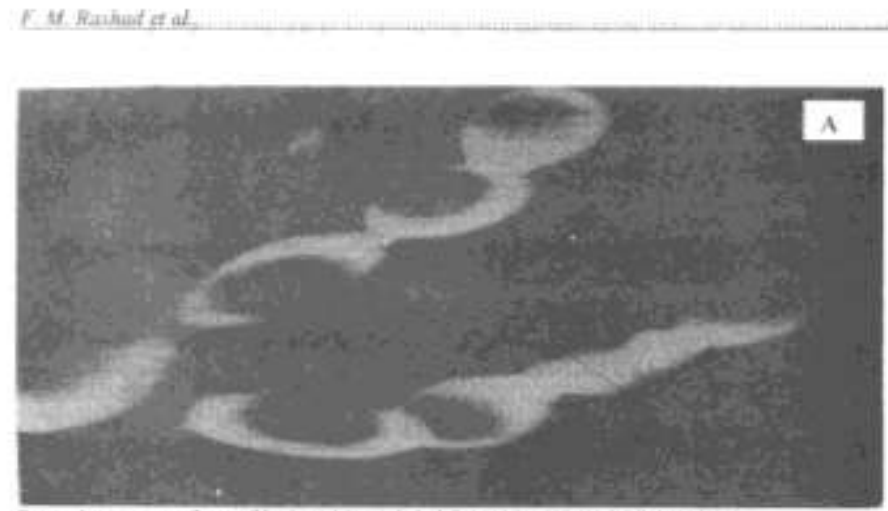

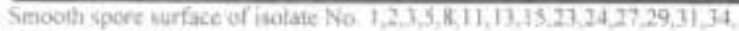

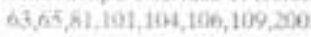
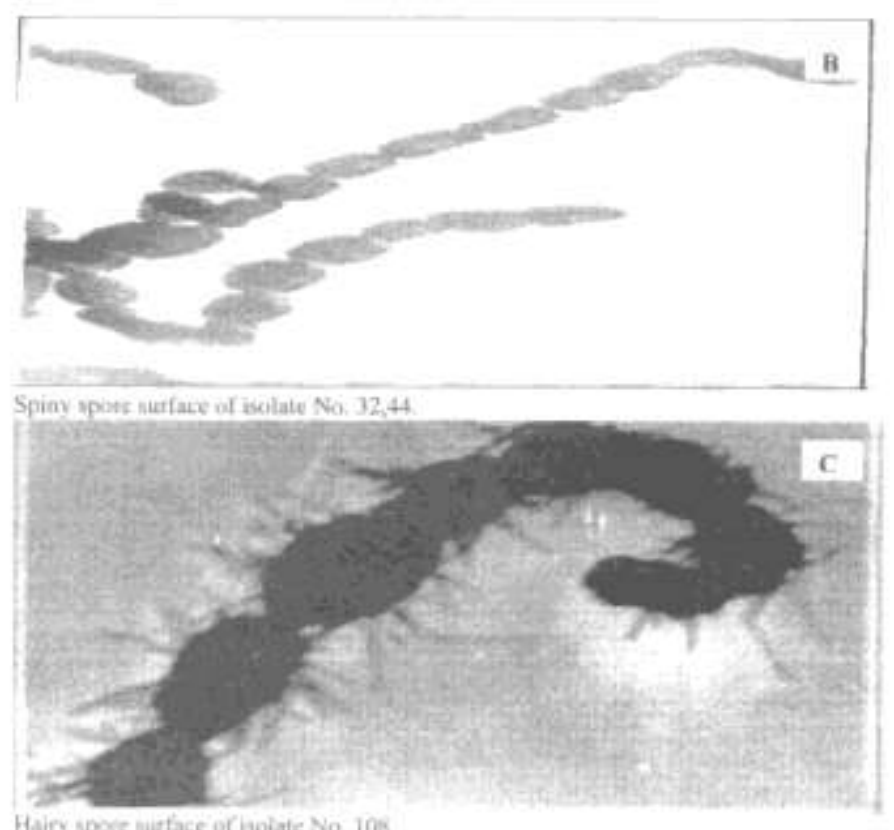

Hairy spore mirface of hoiate No 10 e

Fle. $21:$ Morphalogical characteristics of spore sarface of struptouycetes isodates (Ptotograph $25000 \mathrm{X}$ ). 


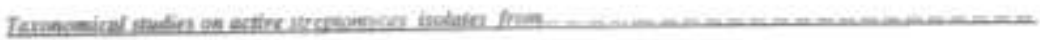

Tabie (20: Morpholegical and coltural characteristics of active Sereptomyce holates

\begin{tabular}{|c|c|c|c|c|c|}
\hline $\begin{array}{l}\text { No. of } \\
\text { active } \\
\text { isolates }\end{array}$ & $\begin{array}{l}\text { Spere chain } \\
\text { morpholeng }\end{array}$ & $\begin{array}{c}\text { Spore chais } \\
\text { ornameatatien }\end{array}$ & $\begin{array}{c}\text { Colour uf spore } \\
\text { mass }\end{array}$ & $\begin{array}{l}\text { Fgunzntation of } \\
\text { substrate ayselium }\end{array}$ & $\begin{array}{l}\text { Diffurible } \\
\text { pigment }\end{array}$ \\
\hline 1 & Survight & Sencoth & Mcotium gry & Lighe brown & Colontes \\
\hline 2 & Spiral & Sinooll & Groyish bowwe & Light brown & Colvirless \\
\hline 3 & Spiral & Snocit & Ligher grey & Orange zellors & Colonteas \\
\hline 3 & Spirat & Sanooth & Medium gatey & Eigha brown & Coloriess \\
\hline 8 & Soraight & Sencoth & Medium gory & Light brown & Coliarios \\
\hline 11 & Straight & Smooth & Medium ggey & Pale yellow & Calorless \\
\hline 13 & Hook & Smooith & Medium arey & Pale jellowe & Coliontess \\
\hline 15 & Sirnight & Suncoilh & Yellowish whise & Orange yellow & Coloriess \\
\hline 23 & Spind & Simocih & Mediuan grey & Lighti beown & Colorios \\
\hline 24 & Spiral & Sincorh & Duksey & Brownish yellow & Caloetera \\
\hline 27 & Straight & Sinoceh & Mediam grey & Pale yellow & Coloriess \\
\hline 29 & Spiral & Senooth & Dark pey & Dark brownist yellow & Coloriess \\
\hline 31 & Spinal & Senooth & Yellowish white. & Orange gelleww & Coloeden: \\
\hline 32 & Spiral & Spiny & Dark grey & Pale yellow & Coloriess \\
\hline 34 & Spiral & Sanvoth & Light gey. & Pale yellow & Colorless \\
\hline 44 & Spinal & Spiny & Dark gey. & Yellowish white & Colorless \\
\hline 63 & Spiral & Simooch & Mrdium grey & Paie yellow & Cotoriess \\
\hline 65 & Floxibilis & Smooth & Yellowish white & Orang yellow & Colneriest \\
\hline 31 & Plesibilis & Simooth & Light gey & Pale yellow & Coloriest \\
\hline 101 & Spiral & Sinocilh & Durk pey & Durk bown & Colorless \\
\hline 104 & Spiral & Smocith & Lighi grey & Dark orange trown & Colorless \\
\hline 106 & Spiral & Smocih & Mediuen zrey & Pule yellow & Colintess \\
\hline 108 & Spinal & Hairy & Medium yerey & Pals yellow & Cobotien \\
\hline 100 & Straight & Senoph & Yellowsish while & Light yeilow brows & Coburies \\
\hline 200 & Straight & Sesooth & Light ges: & Light yellow brown & Coloriess \\
\hline
\end{tabular}


E.M. Rasual te ol

\begin{tabular}{|c|c|c|}
\hline \multirow{2}{*}{ Characteristics } & \multicolumn{2}{|c|}{ Number of strains } \\
\hline & (Positive) & (Negutive) \\
\hline $\begin{array}{l}\text { Dilization of different } \\
\text { carben source } \\
\text { Ciluccese }\end{array}$ & $\begin{array}{l}1,2,3,5,8,11,13,15,23,24,27,29 \\
31,32,34,44,63,65,81,101,104, \\
106,108,109\end{array}$ & 200 \\
\hline D-tractiane & $\begin{array}{l}1,2,5,8,11,13,15,23,24,27,29 \\
31,32,34,44,63,65,81,101,104 \\
106,108,100\end{array}$ & 3,200 \\
\hline Suctuace & $\begin{array}{l}1,2,3,5,4,11,13,15,23,24,27,29,31 \\
32,34,44,63,65,81,101,104 \\
106,106,109\end{array}$ & 200 \\
\hline Xylone. & $\begin{array}{l}1,2,5,8,11,13,15,23,24,27,29 \\
31,32,34,44,63,65,81,101,104 \\
106,108,109\end{array}$ & 3.200 \\
\hline L. Arabinue & $\begin{array}{l}1,2,3,5,8,11,15,13,23,24,27,29 \\
31,32,34,44,6,7,65,51,101,104, \\
106,108,109\end{array}$ & 200 \\
\hline Rallinos & $\begin{array}{l}1,2,3,5,8,11,13,23,24,27,29 \\
31,32,34,63,81,101,104,106\end{array}$ & $13,44,65,108,100,200$ \\
\hline Galuctiose & $\begin{array}{l}1,2,3,5,8,11,15,15,23,24,27,29 \\
31,32,44,44,63,65,51,101,104 \\
106,106,109,200\end{array}$ & None \\
\hline Rhamnowe & $\begin{array}{l}1,2,3,5,8,11,13,15,23,24,27,29 \\
31,32,34,44,43,65,81,101,204 \\
106,108,109,200\end{array}$ & None \\
\hline D-mannital & $\begin{array}{l}1,2,35,8,11,13,15,22,24,27,29 \\
31,32,34,44,63,65,81,101,104 \\
106,108,109,200\end{array}$ & None: \\
\hline $\begin{array}{l}\text { Eisyme Activities: } \\
\text { Proteolytic }\end{array}$ & $\begin{array}{l}2,5,11,13,15,23,27,29 \\
31,32,34,44,63,65,51,101,104 \\
109,200\end{array}$ & $1,3,8,24,106,108$ \\
\hline Lipolytic: & $\begin{array}{l}1,5,11,23,27,29,4,91,106 \\
106\end{array}$ & $\begin{array}{l}2,3,8,13,15,24,31.32,4 \\
4,53,65,101,106 \\
100,200\end{array}$ \\
\hline Lecithinase & $\begin{array}{l}2,3,8,15,23,24,27,29 \\
31,34,63,65,81,101,104,108,109,200\end{array}$ & $1,3,11,13,32,44,106$ \\
\hline
\end{tabular}

(Continued) 


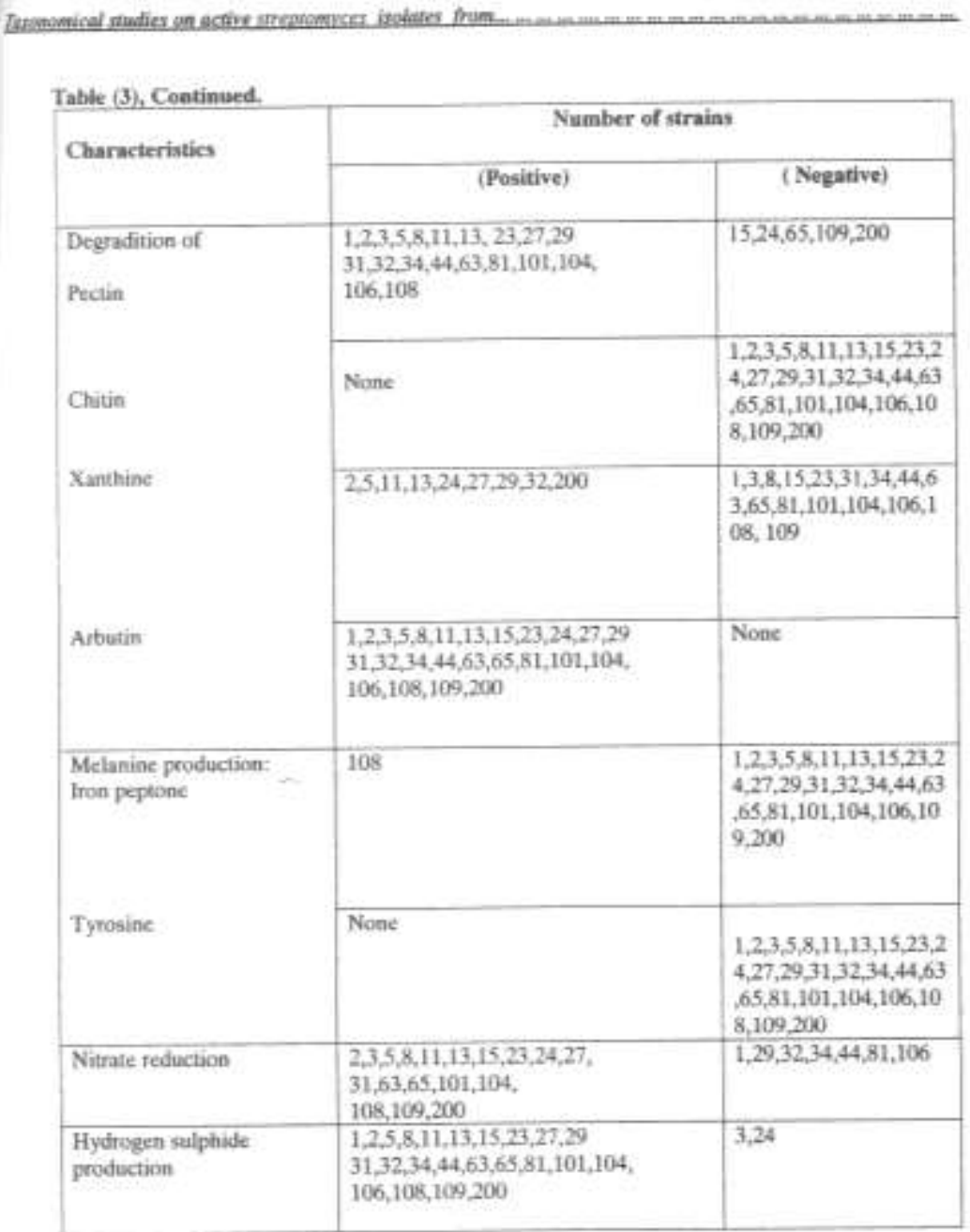


spirals (Fig.1-C) and 2 (8\%) possessed flexibilis or flexous (Fig.1-D). The majority of the isolates $(88 \%)$ showed smooth spore surface (Fig.2-A) as indicated by the transmission electron microscope; however, only 8 and $4 \%$ showed spiny (Fig.2-B) and hairy spore chain ornamentation, respectively (Fig.2-C).

\subsection{Cultural characteristics of active isolates}

As shown in Table (2), the majority of the isolates $21(84 \%)$ belonged to the grey color series and only 4 (16\%) were yellowish white. Diffusible pigments were not detected for all these isolates.

\subsection{Physiological and biochemical characteri- stics of active isolates}

The physiological properties of the active isolates are transcribed in Table (3). The 25 isolates varied in their ability to assimilate various carbon sources, all of them utilized D manitol, rhamnose and galactose ; 24 utilized glucose, sucrose and $\mathrm{L}$ arabinose; 23 utilized $\mathrm{D}$ fructose and Xylose; however, only 18 isolates utilized raffinose. Concerning the enzyme production, it was found that $76 \%$ of the active isolates were proteolytic, $40 \%$ lypolytic, $68 \%$ produced lecithinase, $84 \%$ degraded pectin, $36 \%$ degraded xanthine and $100 \%$ degraded arbutin however, none of them degraded the chitin. Most isolates (23) produced $\mathrm{H}_{2} \mathrm{~S}$ and 19 were nitrate reducers. None of the isolates synthesized melanoid pigments on tyrosine agar medium; however, it was produced by only one isolate on peptoneyeast extract-iron agar.

\section{5. Chemotaxonomy}

Scrutiny of the whole-cell hydrolysate of the active isolates proved that all have a chemotype I cell wall characterized by LL-DAP acid. No diagnostic sugars were found.

\section{6. Identification of Streptomyces strains}

On the basis of morphological, physiological, biochemical and chemotaxonomical characteristics and using the computerized data base to compare the biological properties of the active isolates with those of other Streptomyces spp., the strains were subjected to hierarchical cluster analysis using the similarity matching coefficient $\left(\mathrm{S}_{\mathrm{sm}}\right)$ and clustered by UPGMA. At $94 \%$ similarity many clusters were formed. The first cluster contained ten strains all united at $97 \%$ similarity level and identified as Streptomyces lydicus. The second cluster is connected with a single member phenon of Str. griseoflavus. The third cluster containing 8 strains united at $94 \%$ similarity matrix, was identified as Str. atroolivaceus. The fourth cluster contained one strain and was nearly identical to Str. violacensniger. The fifth cluster contained two strains which were identical to Streptomyces microflavus. The last cluster contained three strains,all of which were identical to Steptomyces anulatus. The obtained results are illustrated in a dendogram (Fig. 3).

\section{DISCUSSION}

Streptomyces have been recognized as the most plentiful source of microorganisms for all types of secondary bioactive metabolites that have crucial applications in human medicine as anti-microbial and anti-cancer compounds and in agriculture fields as herbicides, insecticides and antiparasitic compounds (Watve et al., 2001). Streptomyces are widely represented in nature by the largest number of species and varieties. They differ greatly in their morphology, physiology and biochemical acitvities producing the majority of known antibiotics (Taddei et al., 2006). As correspond to their habitat, these bacteria are nutritionally quite versatile and the most to produce extracellular hydrolytic enzymes that permit the utilization of high molecular weight biopolymers such as proteins, polysaccharides, fats and other substrates (Antanova- Nikolova et al., 2004).

Depending upon colony characteristics of streptomycetes, 200 putative isolates were obtained, only 25 showed variable antimicrobial activities against the tested organisms of Gram negative, Gram positive bacteria, yeasts and filamenous fungi. The degree of antimicrobial activity of the antagonestic isolates was evaluated depending on the mean diameter of the inhibition zone in $\mathrm{mm}(\varnothing \mathrm{mm})$ and divided to the following groups: very weak $(\varnothing<16 \mathrm{~mm})$, weak $(\varnothing 16-19$ $\mathrm{mm})$, moderate $(\varnothing 20-30 \mathrm{~mm})$ and high activity (Ø $30 \mathrm{~mm}$ or more) according to Landerkin et al., (1950).

Various classifications were contrived to conciliate the increasing number of Streptomyces species, most of them are based on a few intuitively chosen morphological and pigmentation properties which were rarely studied under standardized growth conditions (Atalan et al., 2000). Biochemical, nutritional and physiological characters used in streptomycetes taxonomy, usually had been applied to only selected species (Williams et al., 1983; Kutzner et al., 1989 and Schlegel, 1992)

A comparative analysis of the obtained results concerning morphological, physiological, biochemical and chemotaxonomical characteristics using SPSS statistical software devided the 25 bioactive streptomycetes into 6 clusters. The 
first major cluster contained ten isolates nearly identical to Streptomyces lydicus, showing activity
(Crawford et al., 1993; Yuan and Crawford, 1995 and Tokala et al., 2002).

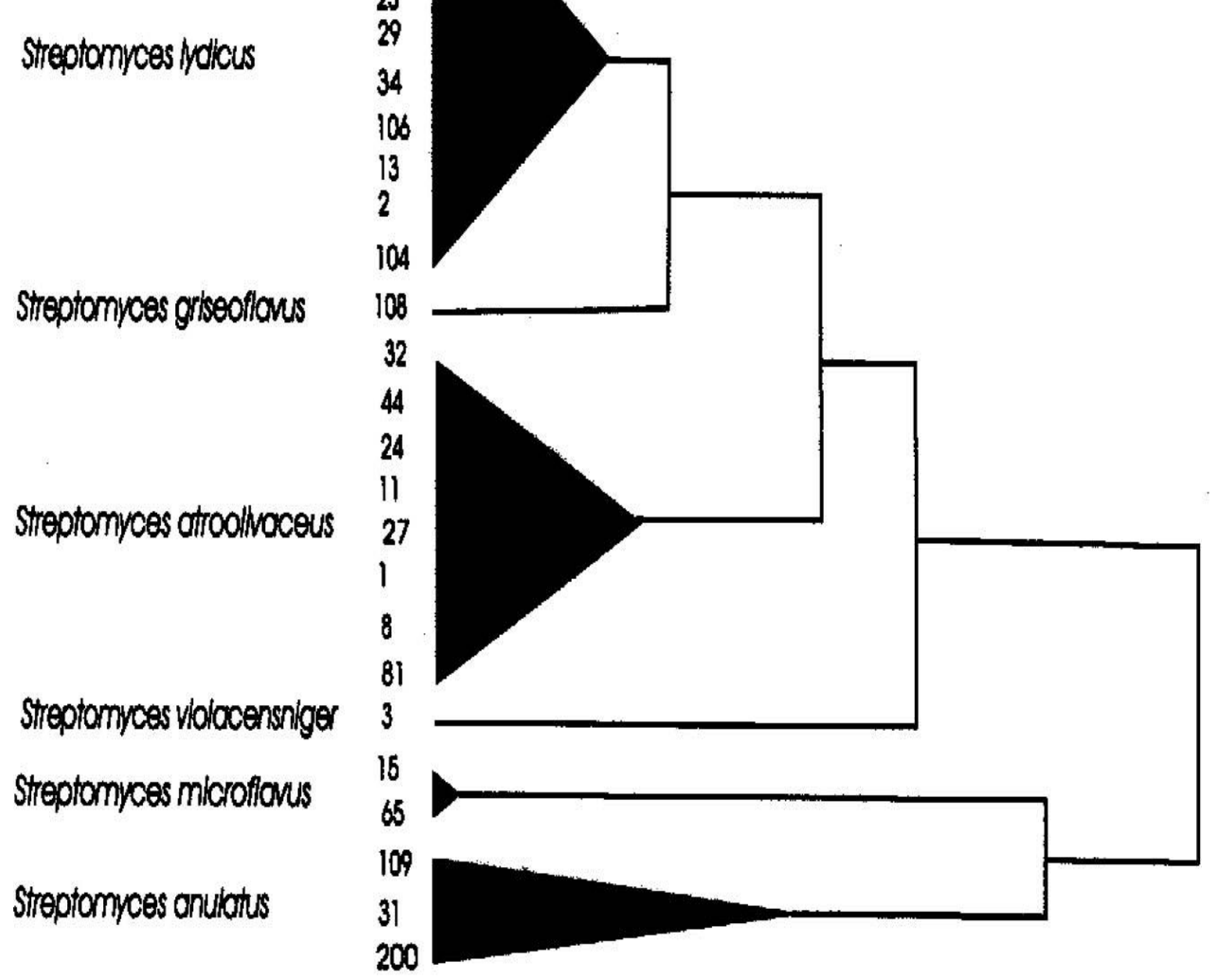

Fig (3): Dendrogram of active Streptomyces species isolated from the different Egyptian soils.

against Gram-positive bacteria and fungi. Streptomyces lydicus isolated by Singh and Gurusiddaiah (1984) from the deep-pitted lesion of potato tubers, was found to produce a new polypeptide antibiotic named chandramycin which showed activity against several of Grampositive and a few Gram negative species of bacteria. It also showed a strong activity against anaerobic microorganisms. The strain of Streptomyces lydicus WYEC 108 was found to act as antifungal biocontrol agent and as a plant growth promoting bacterium in the absence of fungal pathogen challenge as well as a root colonizing active actinomycete which influence the pea root nodulation by increasing nodulation frequency at the infection level by Rhizobium spp.

\section{Percentage similarity (Ssw)}
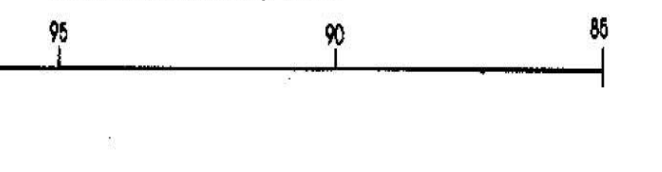
activity against Gram-positive bacteria, yeast and filamentous fungi (Stajner, et al., 1973).

The strain no. 3 which belongs to the fourth cluster is nearly identical to Str. violacensniger, showed activity against Aspergillus niger only. Höltzel et al. (1998) isolated spirofungin as a new antifungal antibiotic from Streptomyces violacensniger Tü 4113 which shows various activities, particularly against yeasts.

In the same year, Trejo-Estrada et al.(1998) discovered that the strain Streptomyces violacensniger YCED-9 produces three antimicrobial compounds with antifungal activity, AFA (Anti-Fusarium activity) a fungicidal active against most fungi except oomycetes; nigricin, a fungistatic polyether; and geldanamycin, a benzoquinoid polyketide highly inhibitory on mycelial growth indpendently. Hayakawa et al., (2004) reported that $77 \%$ of the total streptomycete isolates were assigned to the Streptomyces violacensniger cluster, these isolates had broad antimicrobial spectra as they inhibited the growth of all tested Gram positive bacteria, yeasts and filamentous fungi.

The fifth cluster contained two strains that are identical to Streptomyces microflavus, showed activity against fungi only. Fattiviracins (FV) as antiherpetic antibiotics are produced by Streptomyces microflavus as reported by Uyeda (2003) the strain found to produce at least 13 derivatives (FV-1 to FV-13). He added that fattiviracins have a potent activity against enveloped DNA viruses such as herpes family and enveloped RNA viruses such as influenza A and B viruses.

The three strains identical to Steptomyces anulatus are found in the last cluster and showed activity against Gram-positive bacteria, yeast and fungi. Praveen et al.,(2008) found that the biologically active strains: Streptomyces halstedii MTCC 6817 and Streptomyces anulatus MTCC 6818 produced the same antibiotic that was chemically characterized as actinomycin-D. As reported by Philipp et al.,( 2002), a detailed screening of the secondary metabolite pattern produced by different athropod associated strains of the species Streptomyces anulatus resulted in the isolation and structure elucidation of the endophenazines A-D $(2,4-6)$.

\section{Conclusion}

The 200 putative streptomycetes were isolated from different fertile soil samples. Screening was carried out according to their biological activity revealed that only 25 isolates showed uneven antagonistic effect against the forecited test organisms. A comparative analysis of the obtained results concerning morphological, physiological, biochemical and chemotaxonomical characteristics using SPSS statistical software divided the 25 bioactive streptomycetes into 6 clusters: Streptomyces lydicus, Streptomyces griseoflavus, Str. atroolivaceus, Str.violacensniger, Streptomyces microflavus and Steptomyces anulatus.

\section{REFERENCES}

Alderson G., Goodfellow M. and Minnikin D.E. (1985). Menaquinone composition in classification of Streptomyces and other sporaactinomycetes. J. Gen. Microbiol., Vol.131: 1671-1979.

Antanova-Nikolova S., Tzckova N., and Yocheva L. (2004). Taxonomy of Streptomyces sp. Strain 3B. J. Culture Collections., Vol.4: 3642.

Atalan E., Manfio G.P., Ward A.C., Kroppenstedt R.M. and Goodfellow M. (2000). Biosystematic studies on novel streptomycetes from soil. Antonie Van Leeuwenhoek., Vol.77: 337-53.

Basilio A., González I., Vicente M.F., Gorrochategui J., Cabello A., González A. and Genilloud O. (2003). Patterns of antimicrobial activities from soil actinomycetes isolated under different conditions of $\mathrm{pH}$ and salinity. Appl. Microbiol., Vol. 95: 814-823.

Christova K., Sholeva Z. and Chipeva V. (1995). Application of molecular biological methods in taxonomy of genus Streptomyces. J. Culture Collections., Vol.1: $3-10$.

Crawford D.L., Lynch J.M., Whipps J.M. and Ousl M.A. (1993). Isolation and characterization of actinomycete antagonists of a fungal root pathogen. Appl. Environ. Microbiol., Vol.59: 3899-3905.

Grote R. and Zeeck A. (1988). Metabolic product of microorganisms colabomycins, new antibiotics of the manumycin group from Streptomyces griseoflavus. J. Antibio., Vol.22: 1186-1195.

Hayakawa M., Yoshida Y. and Limura Y. (2004). Selective isolation of bioactive soil actinomycetes belonging to the Streptomyces violaceusniger phenotypic cluster. Appl. Microbiol., Vol.96: 973-981.

Horan A.C. (1999). Secondray metabolite production actinomycetes other than Streptomyces. In Encyclopedia of 
Bioprocess Technology: Fermentation, Biocatalysis and Bioseparation. Flickinger M.C. and Drew S.W. New York: Wiley and Sons. pp. 2333-2348.

Höltzel A., Kempter C., Metzger J.W., Jung G., Groth I., Fritz T. and Fiedler H.P. (1998). Spiroungin, a new antifungal antibiotic from Streptomyces violaceusniger Tü 4113. J Antibiot. (Tokyo)., Vol.1: 699-707.

Kenneth L.K. (1958). Prepared research paper Rp2911, Central Natations for the Revised ISCC-NBS color name blocks. J. Res. NBS., Vol.16: 427.

Kutzner H.J., Locci R., Preobrazhenskaya T.P., Seino A. and Williams S.T. (1989). Streptomyces and related genera. Bergey's Manual of Systematic Bacteriology. Vol.4: 2552-2569.

Landerkin C.B., Smith J.R.C. and Lochhed A.G. (1950). A study of the antibiotics activity of actinomycetes from soils of Northern Canada. Can. J. Res. Sec., Vol.26: 690-698.

Lazzarini, A., Caveletti L., Toppo G. and Marinelli F. (2000). Rare genera of actinomycetes as potential producers of new antibiotics. Antonie Van Leeuwenhoek., Vol.78: 399-405.

Lechevalier M.P. and Lechevalier H.A. (1970). Chemical composition as a criterion in the classification of aerobic actinomycetes. Int. J. Syst. Bacteriol., Vol.20: 435-443.

Lechevalier M.P. and Lechevalier H.A. (1980). The chemotaxonomy of actinomycetes. In Dietz and Thager (Editors) Actinomycetes Taxonomy. Special Publication 6, Society for Industrial Microbiology. Arlington vn. p. 227-291.

Locci R. (1989). Streptomyces and related Genera. Bergey's Manual of Systematic Bacteriology. Williams Company, Baltimore. Vol. 4: p.2451-2508.

McCarthy A.J. and Williams S.T. (1992). Actinomycetes as agent of biodegradation in the environment. A Review Gene. Vol., 115: 189-192.

Minnikin D.E., Hutchinson I.G., Caldicott A.B. and Goodfellow M. (1980). Thin layer chromatography of methanolysates of mycolic acid containing bacteria. J. Cromatogr., Vol.188: 221-233.

Oskay M., Tamer A.Ü. and Azeri C. (2004). Antibacterial activity of some actinomycetes isolated from farming soils of Turkey. African J. Biotechnology., Vol. 3: 441-446.
Philipp K., Axel Z., Klaus G., Hans-Peter F. and Joachim R. (2002). Endophenazines A-D, new phenazine antibiotics from the athropod associated endosymbiont Streptomyces anulatus II. Structure elucidation. J. Antibio., Vol.55: 801- 806.

Praveen V., Tripathi C.K.M. and Bihari V. (2008). Studies on optimum fermentation conditions for actinomycin-D production by two new strains of Streptomyces spp. Med. Chem. Res., Vol. 17:114-122.

Saito N., Kurosawa K., Xu J., Okamoto S. and Ochi K. (2003). Effect of $S$ Adenosylmethionine on antibiotic production in Streptomyces griseus and Streptomyces griseoflavus. Actinomyc etologica., Vol.17 : 47-49.

Sanglier J. J., Haag H., Huck J. A. and Fehr T. (1996). Review of actinomycetes compounds 1990-1995. Expert Opinion and Investigational Drugs., Vol.5: 207-223.

Schlegel H.G. (1992): General Microbiology, 7th ed. Cambridge University Press.

Shirling E.B. and Gottlieb D. (1966). Methods for Characterization of Streptomyces Species. Int. J. Syst. Bacteriol., Vol.16: 313-340.

Shirling E.B. and Gottlieb D. (1968). Cooperative description of type cultures of Streptomyces. III. Additional species description from first and second studies. Int. J. Syst. Bacteriol., Vol. 18:69-189.

Singh S.K. and Gurusiddaiah S. (1984). Production, purification, and characterization of chandramycin, a polypeptide antibiotic from Streptomyces lydicus. Antimicrob Agents Chemother., Vol.26: 394-400.

Sokal R.R. and Michener C.D. (1958): A statistical method for evaluating systematic relationship. Actinomycetes of Littoral and Sub- Littoral Zones of the white Sea. Antibiotiki., Vol. 17:387-392.

Soput J., Lechevalier P.M. and Lechevalier H.A. (1967). Chemical composition of variants of aerobic actinomycetes. Appl. Microbiol., Vol.13: 1356-1361

Stajner K., Blumauerova M., Callieri D.A.S. and Vaněk Z. (1973). The study of variability and strain selection in Streptomyces atroolivaceus II. Chromatographic analysis of mithramycin-producing and nonproducing strains. Folia Microbiologica., Vol.19: 498-506.

Szabo I.M., Marton M., Buti I. and Fernades C. (1978). A diagnostic key for the 
identification of species Streptomyces and Streptoverticillium included in the International Streptomyces Project. A. Bot. Acad. Sci., Hung., Vol.21: 387-418.

Taddei A., Valderrama M., Giarrizzo J., Rey M. and Cadtellic C. (2006). Chemical screening: A simple approach to visualizing Streptomyces diversity for drug discovery and further research. Research Microbiol., Vol.157: 291-297.

Takahashi Y. and Omura S. (2003). Isolation of new actinomycetes for the screening of new bioactive compounds. J. Gen. Appl. Microbiol., Vol.49:141-154.

Tokala R.K., Strap J.L., Jung C.M., Crawford D.L., Salove M.H., Deobald L.A., Bailey J.F. and Morra M.J. (2002). Novel plantmicrobe rhyzosphere interaction involving Streptomyces lydicus WYEC 108 and pea plant (Pisum sativum). Appl. Environ. Microbiol., Vol.68: 2161- 2171.

Trejo-Estrada S.R., Paszczynski A. and Crawford D.L.(1998). Antibiotic and enzyme produced by biocontrol agent Streptomyces violaceusniger YCED-9. J. Ind. Microbiol. Biotechnol., Vol. 21: 81-90.

Tresner H.D., Davis M.C. and Backus E.J. (1961). Electron microscope of Streptomyces spore morphology and its role in species differentiation. J. Bacteriol., Vol.81:70-80.

Ubukata M., Shiraishi N., Kobnata K., Kudo T., Yamaguchi I., Osada H., Shen Y.C. and Isono K. (1995). RS-22A, B and C: new macrolide antibiotics from Streptomyces violaceusniger. I. Taxonomy, fermentation, isolation and biological activities. $J$. Antibiot. (Tokyo)., Vol. 48: 289-292.

Uyeda M. (2003). Fattiviracins, antiviral antibiotics produced by an actinomycete. Actinomycetologica., Vol.17: 57-66.

Waksman, S.A. (1962). The Actinomycetes vol.III, Antibiotics of Actinomycetes. The Williams and Wilkins company, USA.

Watve M.G., Tickoo R., Jog M.M. and Bhole B.D. (2001). How many antibiotics are produced by the genus Streptomyces? Arch. Microbiol., Vol.176: 386-390.

Williams S. T., Goodfellow M., Alderson G., Willigton E.M.H., Sneath P.H.A. and Sackin, M.J. (1983). Numerical classification of Streptomyces and related genera. Gen. Microbiol., Vol.129: 17431813.

Williams S.T., Goodfellow M. and Alderson G. (1989). Genus Streptomyces Waksman and Henrici 1943, 339. In: Bergy's Manual of Systematic Bacteriology, vol. IV, Williams S.T., Sharpe M.E. and Holt J.G. (eds.), Baltimore: Williams and Wilkins, 24522492.

Yuan W.M. and Crawford D.L.(1995). Chracterization of Streptomyces lydicus WYEC 108 as a potential agent against fungal root and seed roots. Appl. Environ. Microbiol.,Vol.61: 3119-3128.

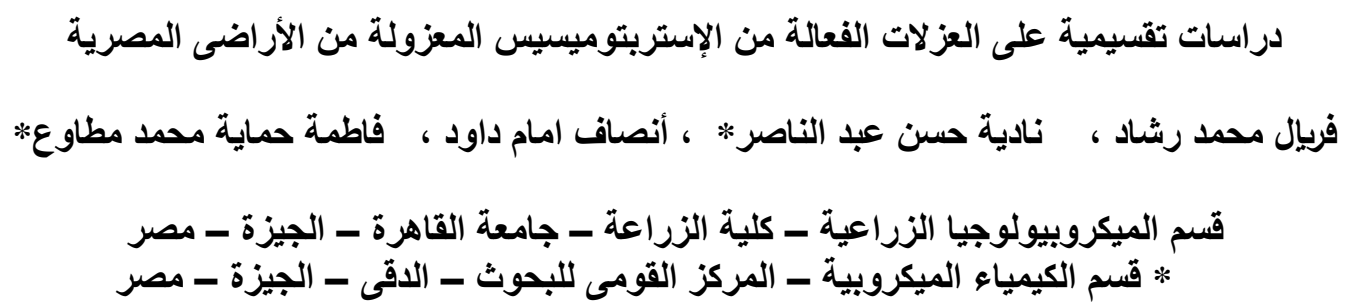

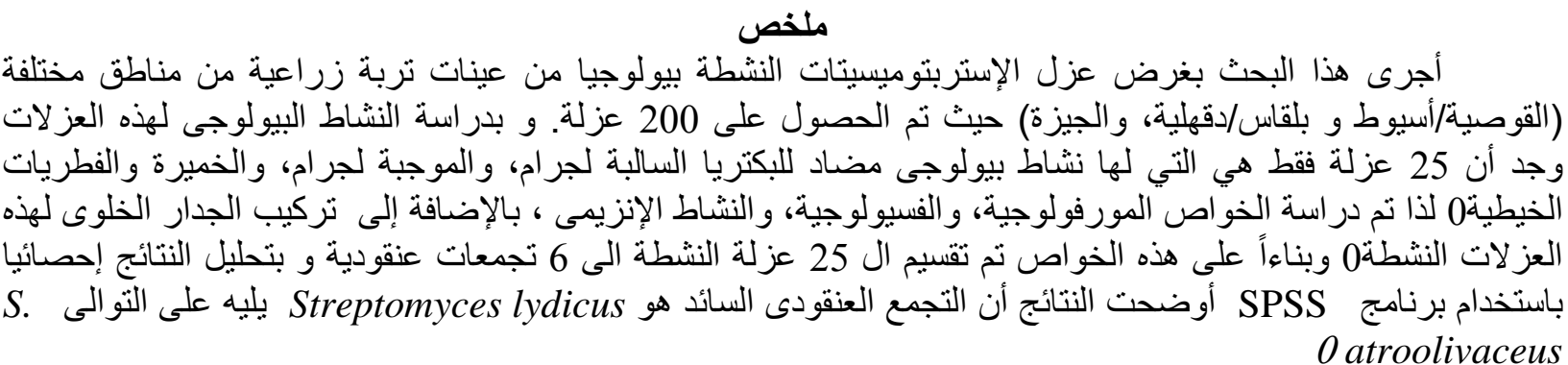

المجلة العلمية لكلية الزراعة - جامعة القاهرة ـ المجلد (60) العدد الثالث (يوليو 2009 ) : 328-315 